\title{
Virtual Management: A Cross-Section Of The Management Process Illustrating Its Fundamental Functions Of Planning, Organizing, Leading And Controlling In A New Era Organization
}

Vlado Dimovski, (E-mail: vlado.dimovski@uni-lj.si), University of Ljubljana, Slovenia Sandra Penger, (E-mail: sandra.penger@uni-lj.si), University of Ljubljana, Slovenia

\begin{abstract}
In the age of the E-Economy, the process of management is undergoing radical changes in all dimensions of basic management functions. New solutions in information and communication technologies are constantly emerging in the forefront, changing and re-defining the current content of management. The traditional management process has built-in competitive advantages on the classic factors of production (land, labor, capital). In the New Economy, the production and distribution of information and knowledge is the main source of a company's assets. The aim of the paper is to present the impact of the New Economy on the management process through its fundamental functions in a new era organization. At the turn of the $21^{\text {st }}$ century, organizations are facing the Internet revolution, which imposes on top management new and different conceptual requirements. Therefore, the paper focuses on the new paradigm of virtual management, and enlightens different theoretical views of the $21^{s t}$ century organization. The results, presented in the paper, can be applied to all companies, competing in today's extremely competitive environment.
\end{abstract}

\section{Introduction}

Management entails the coordination of tasks and activities for the achievement of set objectives and is defined as the creative solving of problems, which occur in the planning, organizing, leading and controlling of resources. In the era of the so-called virtual, digital (Fingarm, Kumar, Sharma, 2000), new (Amor, 2000, Coulter, 1998, Hargrove, 2001, Koch 2000) economy, organizations are facing new types of virtual business operation, which are based on the World Wide Web, Internet ${ }^{1}$. Virtual management is a modern management paradigm, which contributes to all fundamental management functions with the new content of virtual environment. In the following paragraphs of this paper, we present theoretical origins of the contemporary organization and the management paradigm of the $21^{\text {st }}$ century, then we discuss the new content of the management process in the New Economy, and finally we present perspectives of a future organization, with an emphasis on virtual management and global virtual teams.

\section{Theoretical Research}

\footnotetext{
${ }^{1}$ The term electronic business/electronic commerce does not have a generally accepted definition (Coppel, 2000). In the narrower sense it means conducting business over the Internet, electronic selling of goods and services that are delivered through classical means as well as products that can be digitalized and delivered over the Internet. Holsapple and Singh (2000) presented an integral definition of electronic (virtual) business, which associates E-business with the New Economy based on knowledge: E-business is an approach towards achievement of (strategic) business objectives, where knowledge management assures or facilitates execution of activities within and between the value chains, and also enables decision making, which is the foundation for these activities.
} 


\subsection{Method}

This paper is based on the general cognition process research method. The basic method is further expanded with the descriptive method, compilation method, comparative method and synthesis method. The basic research contribution of this paper is its comprehensive theoretical overview of the most modern theoretical findings in the field of organizational theory and management science. Consequently, the presented results are crucial for understanding management and organization paradigm on the doorstep of the 21 st Century. Ensuring business success in today's dynamic environment is increasingly difficult. Therefore it is senior management's role to formulate appropriate corporate strategy that will reflect the requirements of the modern business environment.

\subsection{Major results}

\subsubsection{Challenges of a Modern Organizational Environment and the New Organizational Paradigm}

The challenges that organizations at the beginning of the 21 st century are facing are completely different from the challenges in the 70s' and 80s' of the 20th century. Therefore the organizational concepts and theory of organization are still developing (Palmer, Hard, 2000). Tackling fast changes and a learning process is the most challenging problem modern managers are facing. Many managers are still holding on to the hierarchical, bureaucratic approach for managing organizations, which was dominating during the past decades. The challenges of today's environment - global competition, ethical issues, rapid advance in information and telecommunication technologies, increasing application of electronic operations, knowledge and information, as the most important organizational capital, increasing employee demands for creative work and opportunities for personal and professional development - require completely different response from organizations, as they were used to up until now (Dessler, 2001; Robbins, Coulter, 1999). Patterns, which were used in the past, do not satisfy the guidance needs of the $21^{\text {st }}$ century organization. Today's managers will have to introduce completely new concepts in order to successfully manage a modern learning company. Figure 1 suggests some of the elements involved in the transition from steep hierarchies to networking enterprises (Savage, 1996, page 242).

Figure 1: Transition from Steep Hierarchies to Knowledge Networking

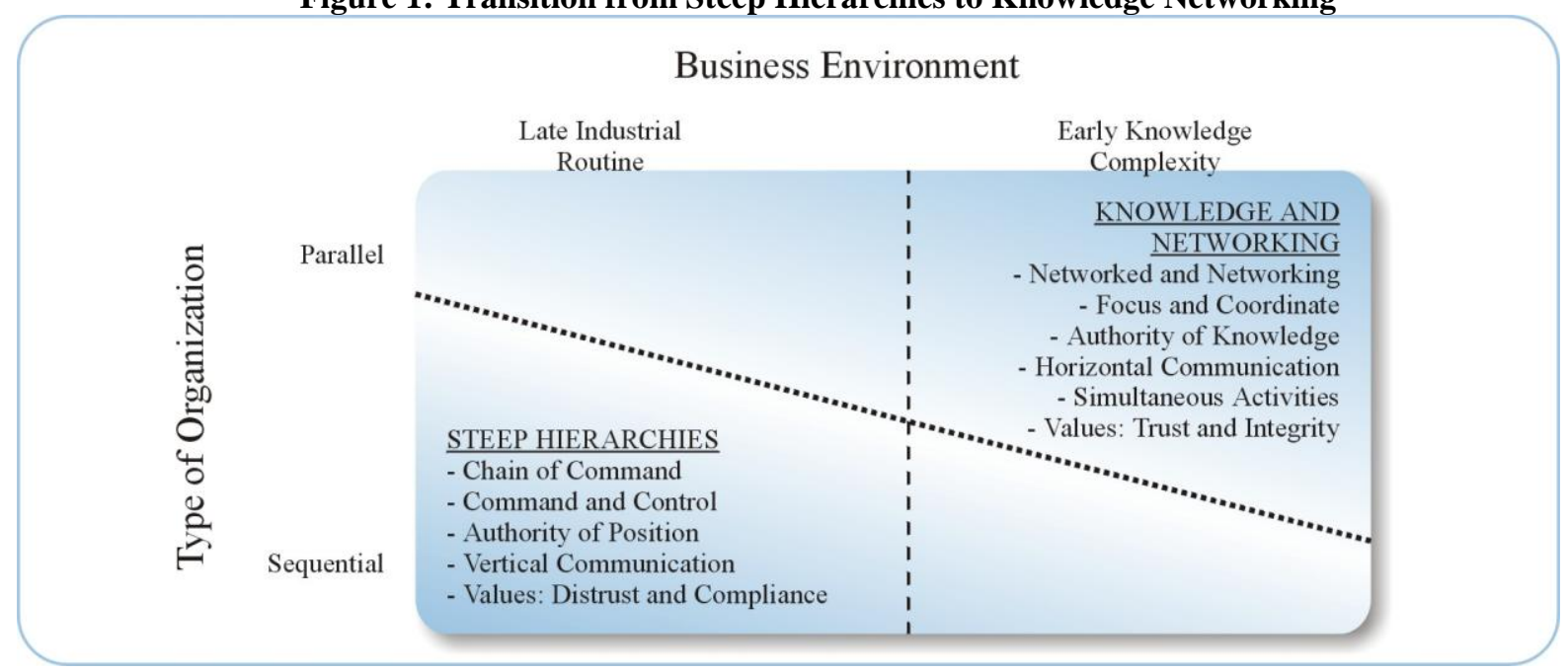

Source: Savage, 1996, page 243

With the intention that modern organizations would more easily face environmental dynamics, they must move toward a new paradigm, which is not based on mechanical assumptions of the industrial age but on the concept of a living biological system. Many organizations are transforming into flexible, decentralized structures, which emphasize horizontal cooperation. Besides that the boundaries between organizations are disappearing more and more, as even the competitors are forming partnerships with intentions to become globally competitive (Hasselbein, Goldsmith, Beckhard, 1997). Primary value of the organizational capital of the modern organizations is not embed- 
ded in buildings and machinery, but in information and knowledge. The market value of companies, whose product is information technology (for example IBM, Hewlett Packard, Xerox Company, Excite, Yahoo or iVillage), is often a hundred to two hundred times higher than the book value of their assets, while traditional companies' market values and book values of assets of are similar ${ }^{2}$. The key is that a company's market value is made up of a company's financial capital and intellectual capital (Pučko, 1998). Intellectual capital is an intangible asset source, which often isn't stated on the balance sheet and in its broadest aspect includes human and structural capital. Modern learning organizations build their lasting competitive advantages on knowledge and intellectual capital, which also represents the only economic source of the modern organization.

To understand the development of the learning organization of the 21 st century, one should be acquainted with the preceding evolution of the organizational structures (see Figure 2, Daft, Marcic, 2001, page 237). A learning organization represents the highest level of horizontal coordination, where all traces of organizational hierarchy are removed. A learning organization facilitates communication and cooperation by including everybody in problem identification and problem solving process, which enables the organization continuous experimentation, improvement and enlargement of its capabilities (Huczynski, Buchanan, 2001). Such organization is based on equality, open information, low hierarchical levels and culture, which stimulates adaptability and cooperation and thus development of ideas wherever within an organization, so the latter is able to more rapidly discover opportunities and fight with crises. In a learning organization problem solving has the highest value, while traditional organizations follow efficient operations. Modern views on management refer to involvement, qualifications and empowerment of the lower levels of management and workers (Daft, Noe, 2001). Stonehouse and Pembertton (Stonehouse et al., 2000) developed knowledge management and organizational learning model in 1999. Organizations must continuously study the internal and external environment, as well as the relationship between these two, for them to become intelligent organizations. With a goal that an organization would learn faster than its competition, it is crucial to develop an understanding, an organizational learning process and knowledge management. Organizational learning is based on the individual learning of individuals. This has to be structured and held in appropriate forms so it can be effectively transferred and used throughout the entire organization at a later time.

Figure 2: The Evolution of Organization Structures

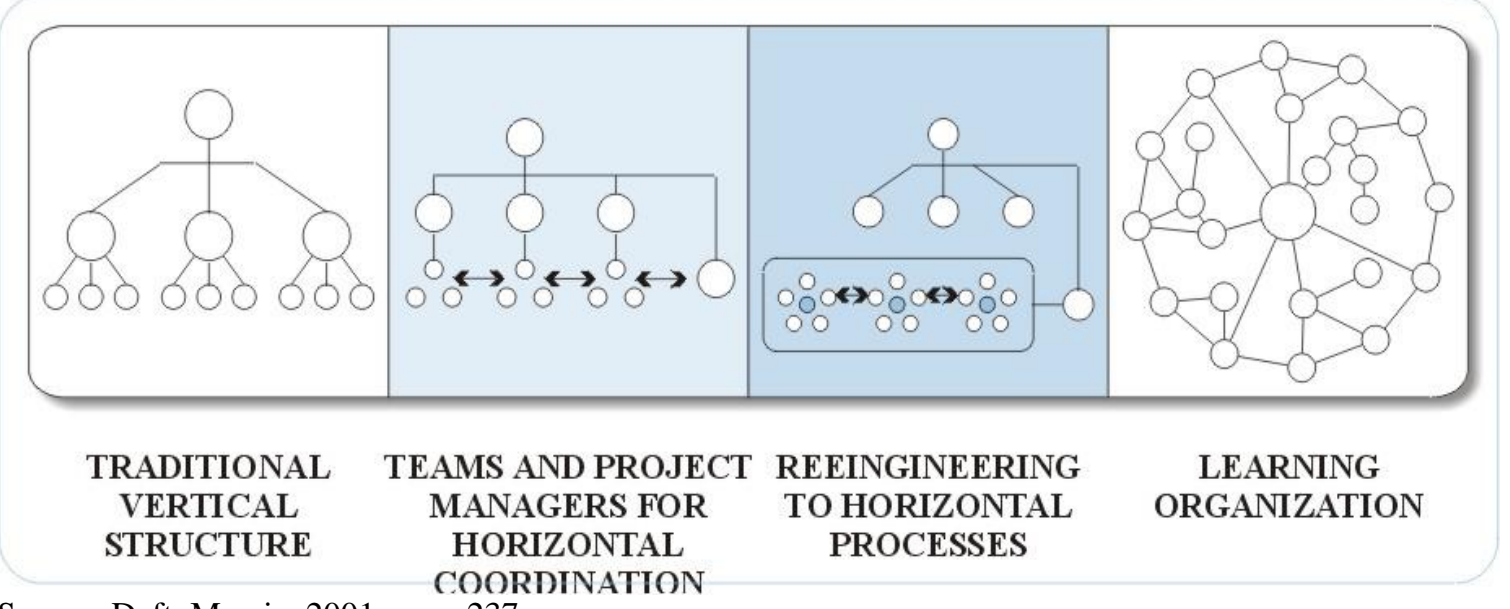

Source: Daft, Marcic, 2001, page 237

\subsubsection{Management Process In The Age Of The New Economy}

The New Economy is gaining ground and establishing a new framework for basic management functions. The future of the management process raises the issues of how to manage information and knowledge and how to develop intellectual capital. Management entails the coordination of tasks and activities for the achievement of set objectives and is defined as the creative solving of problems, which occur in the planning, organizing, leading, and

\footnotetext{
${ }^{2}$ For more info. about this, see: E-Trends: Making Sense of the Electronic Communications Revolution. Cairncross et al. (ed). The Economist, London, 2001. 402 page.
} 
controlling of resources. While managers of the Industrial Age focused their attention on the control of business operations and on hierarchical organizational structures, the New era managers, i.e. E-Managers, will structure and build associations of self-managed virtual teams (Savage, 1996; see also Ashkenas, Francis, 2000; DuBrin, 2000; Earl, Fenny, 2000; Palmer, Hardy, 2000). They will have to be able to create organizational cultures that will reflect the characteristic features of the Internet - openness, knowledge-based approaches, connectivity, experimentality and boundlessness (see Hargrove, 2001). In order to ensure such modern operation of organizations, an exit from the so-called Smith, Taylor and Fayol's bottleneck has to be found. The future has to be built on a new, fifth generation of management, which is based on knowledge networking and emphasizes entrepreneurship and dynamic teamwork. The fifth generation of management is based on five interconnected principles that define the Knowledge era (Savage, 1996): direct knowledge networking, continuous process improvement, comprehension of work as a dialogue, comprehension of time as a critical factor and virtual enterprising, which functions on the basis of dynamic team work. E-Organizations have to implement a horizontal method of work and form teams that concentrate on precisely specified tasks (see Daft, 2001; Palmer and Hardy, 2000;).

1993 was the revolutionary year of the birth of the New Economy (Zerdick et al, 2000, page 141). This was when the web browser MOSAIC was turned over by University of Illinois for commercial use (Coppel, 2000, page $6)$. This is when the Internet, which before served only as computer network for data transfer among academic and research institutions, was changed to an integrated network intended for commercial business purposes. Business subjects started using the benefits of global Internet network to support their operations (Amor, 2000, page 34). Companies operate in the economy, which is directed by knowledge, and therefore more and more function as organizations that are based on knowledge. In the New Economy the value of knowledge as an input as well as output is increasing (Holsapple and Singh, page 159), since it is the key content, which we are buying and selling, explicitly as well as implicitly. The importance of knowledge as a resource is increasing, in comparison to traditionally recognized resources (financial, material), at the same time new technologies and techniques for knowledge management are being formed, such as Lotus Notes or the Internet (Coulter, 1998, page 44, Cross, Baird, 2000, page 71).

The E-Economy has introduced new dimensions into basic managerial functions. A new planning paradigm becomes evident through the decentralized planning approach, with lower hierarchical levels involved in the planning process (Daft and Marcic, 2001; Laudon K., Laudon J. 2000;). Intelligent organizations concentrate on the creation of the new knowledge that embodies the cornerstone of a lasting competitive advantage (Stonehouse et al., 2000). The gaining of a competitive advantage results from the uniqueness of the network connections that the company establishes with its suppliers, distribution channels and end-customers (Etihaj, Guler, Sigh, 2000; Lynch, 2000; see also Porter, 1985; Stonehouse et al., 2000; Werbach, 2000). Such an integrated value network is faced with two simultaneous processes: on the one hand, there is the process of cooperation and integration of value chains into a global value system, and on the other hand, we witness the deconstruction of value chains into individual parts (Koch, 2000; page 274-287; Zerdick et al., 2000, page 99). Traditional value chains become fragmented - deconstructed into numerous business segments within which their own specific bases of competitive advantage will be formed (Margetta, 1999, page 18; Timmers, 1999, page 33).

In the new environment numerous companies are following the learning organization's concept, while new networking virtual organizational structures prevail among these. New flattened organizational structures facilitate communication and cooperation. Thus everybody is involved in identification and problem solving, which enables an organization to continuously experiment, improve and increase its capabilities. Information technology interweaves the organizational structure, which is based on equality, open information, a low level of hierarchy and culture, which facilitates adaptability and cooperation. In a state-of-the-art horizontal organizational structure, the vertical structure shifts top managers away from the technical staff. An extended chain of command inspires the delegation process and consequently the empowerment of the employees. The model of a hypertext organization is gaining ground as an appropriate organizational structure composed of three layers: a business-system layer, a project-team layer and a knowledge-base layer (Savage, 1996). Modern forms of organizational structures range from horizontal, process and team structures to virtual networks (Daft, 2001).

Ohame (1995, page 270-284) explains that in today's unlimited economy new technologies remove (past) informational inefficiency and therefore there is no need for highly hierarchical pyramids. 
Figure 3: Key Dimensions of the Old and New Organizational relations Paradigm.

\begin{tabular}{|c|c|}
\hline Old views on organizational relations & New organizational relations paradigm \\
\hline Vertical organizational structure; & Horizontal organizational structure; \\
\hline Narrow range of control; & Wide control span; \\
\hline High, steep organizational hierarchy (pyramid); & Low, flattened organizational hierarchy (pyramid); \\
\hline $\begin{array}{l}\text { Bureaucratic, complicated organizational relations, with } \\
\text { many levels within the organizational pyramid; }\end{array}$ & $\begin{array}{l}\text { New, flexible, boundless, virtual organizational relations; orga- } \\
\text { nizational pyramid has less and less levels; }\end{array}$ \\
\hline $\begin{array}{l}\text { Centralized organizational structure and relations; centrali- } \\
\text { zation of decision making only at the top managerial level; }\end{array}$ & $\begin{array}{l}\text { Decentralized organizational relations; decentralized decision } \\
\text { making and transfer of decision making power from high to } \\
\text { lower managerial levels; }\end{array}$ \\
\hline Routine tasks; & Empowered roles of employees \\
\hline Formal control and coordination systems; & $\begin{array}{l}\text { Dissemination of information along the entire organizational } \\
\text { pyramid; horizontal integration of information - management } \\
\text { shares information with employees; }\end{array}$ \\
\hline Competitive inter-organizational strategy; & $\begin{array}{l}\text { Strategy of cooperation and virtual connectedness of organiza- } \\
\text { tion via electronic network; }\end{array}$ \\
\hline $\begin{array}{l}\text { Rigid organizational relations; stable and inadaptable orga- } \\
\text { nizational structure; }\end{array}$ & $\begin{array}{l}\text { Adaptable organizational relations and new dimensions of mul- } \\
\text { ticultural relations; }\end{array}$ \\
\hline $\begin{array}{l}\text { Centralization of activities execution within an organiza- } \\
\text { tion; strictly defined organizational boundaries; }\end{array}$ & $\begin{array}{l}\text { Outsourcing; networking and connectivity of companies in a } \\
\text { virtual system, where organizational boundaries can not be de- } \\
\text { termined; }\end{array}$ \\
\hline Clearly defined organizational boundaries; & $\begin{array}{l}\text { Modern borderless economy connects organizations in a virtual } \\
\text { system, which is primarily focused on value adding in the eyes } \\
\text { of consumers; }\end{array}$ \\
\hline $\begin{array}{l}\text { Traditional organizational structures; vertical functional } \\
\text { structure, divisional structure; }\end{array}$ & $\begin{array}{l}\text { Newer organizational structures; dynamic network structure; } \\
\text { hybrid structure; horizontal matrix structure; virtual network } \\
\text { structure; team structure; }\end{array}$ \\
\hline
\end{tabular}

Figure 3 explains that the move from the vertical to horizontal organizational structure is a fundamental turnaround of the new organizational dimensions. Traditionally the most common organizational structure is the one in which activities are grouped on all levels of the organization. Cooperation between functional departments is in general poor and the whole organization is coordinated and controlled through vertical hierarchy in which decision making jurisdiction belongs to senior management. In a fast changing environment, hierarchical structure becomes overloaded. Senior managers are not capable to respond quickly enough to problems and opportunities. In a modern horizontal organizational structure, vertical structure digresses senior management from technical personnel. Structure is based on horizontal workflows or processes, and less on departmental functions. Self-guided teams represent a basic working unit. There are almost no boundaries between functions, since teams are composed of people from different functional areas.

In the New Economy organizational structures are based on network forms (Burton, 1999, page 137). The key for such structures is that allocation of power is asymmetrically allocated in favor of the central organization, which controls the network. Network organizational structure enables accomplishment of transaction to many, which impacts the formation of communication between all parties in the network. In the New Economy, the model of business networking establishes new forms of electronic connections, which expand existing physical connections and present new possibilities for connecting parties within the network. Coulter (1998, page 349) states that future organizations will undertake one of three possible organizational structure scenarios: team organizational structure, virtual organization or boundless organization. In the era of New Economy, organizational structures are taking on the shape of virtual network structures, which are based on outsourcing; the organizational philosophy of the virtual organizations is based on learning. The phenomenon of the learning organization, as a philosophy on which virtual network organizational structure is based, is the core element that determines the content of the organizational structure of the modern age organizations.

Development of networks also had a radical impact on the area of managerial function of leadership as shown in Figure 4. Virtual management focuses on helping teams and partners to better understand the essence of changes and to reach agreement on what would be the best way to function under the given circumstances (McCarthy, 2000). Virtual management is a result of group processes and not of individual characteristics of individuals. It 
focuses on the question of how to establish values, goals, authority, structure, meaning and work processes within a team. Since more and more activities are outsourced, employees are becoming part of geographically dispersed teams.

Figure 4: Evolution of Management Throughout the Centuries

\begin{tabular}{|l|l|l|}
\hline & INDUSTRIAL ECONOMY & DIGITAL ECONOMY \\
\hline $\begin{array}{l}\text { Organizational } \\
\text { structure }\end{array}$ & Mechanical: & $\begin{array}{l}\text { E-Company network: } \\
\text { Hyper-partnership strategy } \\
\text { Closed boundaries } \\
\text { Monolithic business strategy } \\
\text { Static and stable strategy }\end{array}$ \\
\hline Control & $\begin{array}{l}\text { Power and retention of information: } \\
\text { Fluid and adaptable business structure }\end{array}$ \\
& $\begin{array}{l}\text { Formal authority } \\
\text { Strict hierarchy } \\
\text { Orders }\end{array}$ & $\begin{array}{l}\text { Power sharing and information sharing: } \\
\text { Informal influence } \\
\text { Hyper-connectivity } \\
\text { Conversations }\end{array}$ \\
\hline Acts & $\begin{array}{l}\text { Slow and controlled: } \\
\text { Earned trust } \\
\text { Long-term planning }\end{array}$ & $\begin{array}{l}\text { Fast and approximate business tactics: } \\
\text { Rapid trust } \\
\text { Interactive learning and planning }\end{array}$ \\
\hline Focus & $\begin{array}{l}\text { Individual characteristics: } \\
\text { Collectivity and team focus: }\end{array}$ \\
& $\begin{array}{l}\text { Managing individuals } \\
\text { Individual actions }\end{array}$ & $\begin{array}{l}\text { Managing inside network } \\
\text { Interpersonal relationship skills }\end{array}$ \\
\hline
\end{tabular}

Source: McCarthy, 2000, page 3

The leading new communication tool of the $21^{\text {st }}$ century is the Internet. The coordination of employees, which are dispersed and are at the same time working for different employers, would be extremely difficult and time consuming. Internet technology enables dislocated members of an organization to communicate undisturbed and work on a project. Organizations enable project participants to deploy their products on web pages, so that they are made available to all other team members. Virtual team members communicate electronically by checking individual project points with electronic messages. Effective communications over the Internet of course require open standards that facilitate work for various users. New communication tools connect organizations and its members in a large communication network.

The new role of the future leader will be to help employees cope with the changes that are the key factors of the E-Economy. E-Management is based on horizontal connectedness between members of an organization and, consequently, the role of management is changing and moving from control and limited resources management towards exerting influence on networks of self-interested individuals or units from within and outside an organization. New leadership content emerges in virtual enterprising (Savage, 1996; see also Keys, Fulmer, 1998). Virtual enterprising is a process in which organizations unite their competence and knowledge and establish multiple crossfunctional teams together with members from external organizations.

Virtual global teams were formed in response to quickly changing environmental requirements of the $21 \mathrm{st}$ century organizations and today enable quick coordination of individual members located in geographically dispersed locations (Hersey, Blanchard, Johnson, 1996). Results from formation of global virtual teams are shown in reduced time cycles and reduced transportation costs, and in a considerable decrease in the need for the preservation of an unnecessary labor force along the organizational units. The key characteristic of the global virtual teams is that they create opportunities for the coordination of complex tasks across dispersed networks. Kayworth and Leindner (1999) define communication, culture, technology, project management and leadership process as critical success factors of efficient global virtual teams. 
Figure 5: Characteristics of Successful Virtual Team Leader

\begin{tabular}{|l|l|}
\hline Leadership dimension & Description of the characteristics of successful team leader \\
\hline Communication & $\begin{array}{l}\text { Leader provides and ensures constant feed back; } \\
\text { Leader provides precise and accurate information; } \\
\text { Leader forms clear, detailed picture about tasks. }\end{array}$ \\
\hline Understanding & $\begin{array}{l}\text { Leader shows understanding for coordination of all team member time schedules; } \\
\text { Leader considers opinions and proposals of all team members; } \\
\text { Leader expresses concern and understanding for team members' problems; } \\
\text { Leader shows personal interests towards team members. }\end{array}$ \\
\hline Clarity of roles & $\begin{array}{l}\text { Leader clearly establishes all team members' responsibilities; } \\
\text { Leader knows how to establish its authority to ensure execution of tasks; } \\
\text { Leader is not a distant dictator, but someone who undertakes a role of an advisor. }\end{array}$ \\
\hline Leader's behavior & $\begin{array}{l}\text { Confident, clear leadership behavior and not oppressive or commanding; } \\
\text { Leader's ability to reach down to the level of other team members; } \\
\text { Leader's consistent behavior also after project completion. }\end{array}$ \\
\hline
\end{tabular}

Source: Leinder, Kayworth, Tavarez, 1999, page 27

Traditional team management approaches are gaining new dimensions in the new virtual team environment and among required diverse work practices. Research about key characteristics of a successful virtual team leader, which included twelve culturally diverse global virtual teams from Mexico, USA and Europe, showed that a successful team leader exhibits capabilities to control paradoxical and contradictory matters through simultaneous implementation of various leadership roles (Leinder, Kayworth, Tavarez, 1999). This ability reflects her/his behavioral complexity. A highly successful virtual team leader leads a team as an advisor and shows a high level of understanding toward other team members. She/he is capable of defending her/his authority, without others feeling her/his domination or inadaptability. It is really important that successful virtual team leaders are capable of providing correct, detailed and accurate communication to other virtual team members (see Figure 5).

New economy brings in new dimensions to the control function. The development of information and telecommunication technologies has enabled information to be shared throughout the entire organization and that it is instantly made available. Basi (1998, page 178) states that the control process can be divided into three subprocesses: current achievements supervisory process, sub-process of comparing results with set standards and corrective action sub-process. The business control paradigm is exhibited in the move from formal control systems to new approaches of information sharing (Hargrove, 2001; Laudon K., Laudon J., 2000). Decentralized control relies on cultural values, tradition and trust, thus assuring the conformity of staff activities with the objectives of the organization. Modern control approaches comprise, in particular, market and behavior control, balanced scorecards, international quality standards and open book management (Daft, 2000; Kaplan, Norton, 2000). Balanced score card is a universal control system that balances traditional financial ratios with operative ratios, which are connected with critical success factor of a company. This system includes four major aspects (Kaplan, 2000, Kaplan, Sawhney, 2000): financial aspect, customer relations aspect, learning and growth aspect and internal business processes aspect.

A learning organization is considered to be the top stage of horizontal coordination, with no traces of organizational hierarchy remaining. A learning organization requires specific changes in leadership, management and structure, the delegation of more powers to the employees, communications, participative strategy and adaptive culture. Complete understanding, organizational learning and knowledge management need to be developed, in order for an organization to learn more rapidly than its competitors (Dimovski, 1994; Možina, 2000; see also Daft, Marcic, 2001). A major challenge in knowledge management is the transformation of personal and tacit knowledge into organizational knowledge. Knowledge management is understood to be a process of systematic, proactive management and the development of knowledge in the organization (Holsapple, Singh, 2000). The development can reach levels that some organizations no longer exist in physical form. Then we speak about virtual organizations (Ancona et al., 1999; Coulter, 1998; Laubacher, Malone, 2000; Stonehouse et al., 1999).

In the new virtual environment modern organizations are establishing new methods of virtual management that are based on the global network, Internet and modern information and telecommunication technologies. E-mail and other forms of network connections enable managers a wide control span and management of its members, i.e. global virtual teams regardless of their location. Information can be quickly transmitted to virtual team members, which enables independent virtual working process. Stonehouse et al (2000) states that information technology 
created the birth of the virtual organization. A virtual organization is defined as an interconnected network, which is comprised of an organization's core business activity and its suppliers and buyers, whose activities are integrated and coordinated through broad use of information and communication technology (Skyrme, 1999). Virtual organization produces and distributes products and services through a network of connected people, without being limited with any traditional organizational and physical boundaries (Laudon K., Laudon J., 2000). Virtual organization's organizational structure looks like dynamic network structure (Daft, 2000). It is the newest approach toward departmentalization that spreads the idea of horizontal coordination and cooperation across the borders of an organization.

Virtual organization is defined by several characteristics. Virtual organization is built on the network of connected business subjects and buyers, which are focused on the core activity. An individual network members strictly focus on core business activities; members of virtual network share complementary objectives; organization's network strategy is clearly defined; full integration of business and information strategies exists; members of the virtual network share technology that often includes computer networks, cable communications, common communication standards and electronic data sharing. A pure form of virtual organization focuses strongly on core business activity, which reflects high integration level of internal business activities, with a considerable level of separation between individual functional business areas.

\section{Conclusion}

The objective of this paper is to exhibit the extent of virtual management through the influence of the New Economy on the management process, as a structure of basic functions of planning, leading, organizing and controlling. Consequently different views about the future organization are being formed in the organizational environment of the 21st century. In the New Economy, the production and distribution of information and knowledge is the main source of a company's assets. The future of the management process raises the issues of how to manage information and knowledge, and how to develop intellectual capital. The E-Economy has introduced new dimensions into basic managerial functions. The new role of the future leader will be to help employees cope with the changes that are the key factor of the E-Economy. E-Management is based on horizontal connectedness between organization members and, consequently, the role of management is changing and moving from control and limited resources management towards exerting influence on networks of self-interested individuals or units from within and outside the organization. A learning organization is considered to be the top stage of horizontal coordination, without any traces remaining of an organizational hierarchy. A learning organization requires specific changes in leadership, management and structure, the delegation of more powers to the employees, communications, the participative strategy and adaptive culture. Virtual organization forms and distributes products and services through a network of interconnected people, property and ideas, without being limited with traditional organizational and physical boundaries. It is the newest approach toward departmentalization, which spreads the idea of horizontal coordination and cooperation across organizational boundaries. Global virtual teams were formed in response to rapidly changing requirements of the 21 st century organization's environment and enable fast coordination of individual team members located in geographically dispersed locations.

\section{References}

1. Amor Daniel: The E-Business R-Evolution: Living and Working in an interconnected World. Upper Saddle River: The Prentice-Hall, 2000. p 636.

2. Ancona Deborah et al.: What do we really want? A manifesto for the Organizations of the 21 st Century. MIT Discussion Paper. Cambridge: MIT Sloan School of Management: November 1999. [URL: http://ccs.mit.edu/papers/pdf/wp032manifesto21C.pdf], November 1999.

3. Ashkenas Ronald N., Francis Suzane C.: Integration Managers: Special Leaders for Special Times. Harvard Business Review, Boston, 78 (2000), 11-12: 108-118.

4. Basi Raghbir S.: Contextual Management: A Global Perspective. New York: International Business Press, 1998. 290 str.

5. Burton Jones Alan: Knowledge Capitalism: Business, Work, and Learning in the New Economy. Oxford: Oxford University Press, 1999, 248 str.

6. Coppel Jonathan: E-Commerce: Impacts and Policy Challenges. Economics Department Working Papers No. 252. Paris: Organization for Economic Co-operation and Development (OECD), 2000.

7. Coulter Mary K.: Strategic Management in Action. New Jersey: Prentice-Hall Inc., 1998.

8. Cross Rob, Barid Lloyd: Technology Is Not Enough: Improving Performance by Building Organizational 
Memory. Sloan Management Review, Boston, 41 (2000), 3, str. 69-77.

9. Daft Richard L., Marcic Dorothy: Understanding Management. 3rd ed. Fort Worth: Harcourt College Publishers, 2001.

10. Daft Richard L., Noe Raymond A.: Organizational Behavior. Fort Worth: Harcourt College Publishers, 2001.

11. Daft Richard L.: Organizational Theory and Design. 7th ed. Ohio: South-Western College Publishing, 2001.

12. Dessler Gary: Management: Leading People and Organizations in the 21st Century. 2nd ed. New Jersey: Prentice Hall, 2001.

13. Dimovski Vlado: Organizational Learning and Competitive Advantage: A Theoretical and Empirical Analysis. Doctoral Disertation. Cleveland: [V. Dimovski], 1994.

14. DuBrin Andrew J.: The Active Manager: How to Plan, Organize, Lead and Control Your Way to Success. London: Thomson Learning, 2000.

15. Earl Michael, Feeny David: How To Be a CEO for the Information Age. Sloan Management Review, Boston, 41 (2000), 2: 11-24.

16. Ethiraj Sendil, Guler Sisin, Singh Harbir: The Impact of Internet and Electronic Technologies on Firms and its Implications for Competitive Advantage. Working Paper. Philadelphia: The Wharton School, 2000. [URL: http://fic.wharton.upenn.edu/fic/wfic/papers/00.html], 2000.

17. E-Trends: Making Sense of the Electronic Communications Revolution. Cairncross et al. (ed). The Economist, London, 2001.

18. Fingar Peter, Kumar Harsha, Sharma Tarun: Enterprice E-Commerce. Tampa: Meghan-Kiffer Press, 2000. p. 360.

19. Hargrove Robert: E-Leader: Reinventing Leadership in a Connected Economy. Cambridge: Perseus Publishing: 2001.

20. Hersey Paul, Blanchard Kenneth H., Johnson Dewey E.: Management of Organizational Behavior. 7th ed. London: Prentice-Hall, 1996.

21. Hesselbein Frances, Goldsmith Marshall, Beckhard Richard: The Organizations of the Future. San Francisco: Jossey Bass Publishers, 1997.

22. Holsapple Clyde W., Singh Meenu: Toward Unified View of Electronic Commerce, Electronic Business, and Collaborative Commerce: A Knowledge Management Approach. Knowledge and Process Management, Toronto, 7 (2000), 3: 151-164.

23. Huczynski Andrzej, Buchanan David: Organizational Behavior: An Introductory Text. 4th ed. New York: Prentice Hall, 2001. 916 str.

24. Kaplan Robert S., Norton David P.; Having Trouble with Your Strategy: Then Map It. Harvard Business Review, Boston, 78 (2000), 9-10, str. 167-175.

25. Kaplan Robert S.: Uravnoteženi sistem kazalnikov (engl.: Balanced Scorecard). Ljubljana: The Balanced Scorecard Collaborative, 2000. (In Slovenian Language).

26. Kaplan Steven, Sawhney Mohanbir: E-Hubs: The New B2B Marketplaces. Harvard Business Review, Boston, 78 (2000), 5-6: 97-103.

27. Kayworth T. R., Leidner D.: The Global Virtual Manager: A Perscription for Success. Insead Working Paper 99/67/TM. Fontainebleau: The European Institute of Business Administration, 1999.

28. Keys Bernard J., Fulmer Robert M: Executive Developement and Organizational Learning for Global Business. New York: International Business Press, 1998.

29. Koch Richard: The Financial Times Guide to Strategy: How to Create and Deliver a Useful Strategy, 2nd ed. Great Britain, 2000.

30. Laubacher Robert J., Malone Thomas W.: Retreat of the Firm and the Rise of Guilds: The Employment Relationship in an Age of Virtual Business. 21st Century Initiative, Working Paper No 033. Cambridge: MIT Sloan School of Management: 2000. [URL: http://ccs.mit.edu/papers/pdf/21cWP033.pdf], August 2000.

31. Laudon Kenneth C., Laudon Jane P.: Management Information Systems: Organization and Technology in The Networked Enterprise. 6th ed. New Jersey: Prentice-Hall: 2000.

32. Leidner D., Kayworth T. R., Tavarez-Mora M.: Leadership Effectiveness in Global Virtual Teams. Insead Working Paper 99/68/TM. Fontainebleau: The European Institute of Business Administration, 1999.

33. Lynch Richard: Corporate Strategy. 2nd ed. Harlow: Financial Times Prentice Hall, 2000.

34. Margeta Joan: Managing in the New Economy. Boston: A Harvard Business Review Book, 1999.

35. McCarthy John C.: eLeadership For the Net Economy. The Forrester Research Brief Cambridge: Forrester Group, October 2000. 7 str. [URL: 
http://www.forrester.com/ER/Research/Brief/Excerpt/0,1317,11026,00.html], 16.03.2000.

36. Možina Stane: Učeča se organizacija (engl.: Learning Organization). Organizacija, Kranj, 33 (2000), 7: 468-471. (In Slovenian Language).

37. Ohame Kenichi: The Evolving Global Economy: Making Sense of the New World Order. Boston: The Harvard Business Review Book, 1995. 300 str.

38. Palmer Ian, Cynthia Hardy: Thinking About Management. London: Sage Publications, 2000.

39. Porter Michael E.: Competitive Advantage: Creating and Sustaining Superior Performance. New York: Free Press, 1985.

40. Pučko Danijel: Poslovodenje znanja in vplivi na strateško poslovodenje ter analizo (engl.: Knowledge Management and it's Impact on Strategic Management and Analysis). Organizacija, Kranj, 31(1998), 10, 557-565. (In Slovenian Language).

41. Robbins Stephen P.: Managing Today. 2nd ed. San Diego: Prentice Hall, 2000.

42. Savage Charles M.: Fifth Generation Management: Co-creating Through Virtual Enterprising, Dynamic Teaming, and Knowledge Networking. Boston: Butterworth-Heinemann, 1996.

43. Skyrme David (1999): The Virtual Organization. .[URL: http://www.skyrme.com/insights/2virtorg.htm, 19.04.2002].

44. Stonehouse George et al.: Global and Transnational Business: Strategy and Management. Chichester: Wiley, 2000.

45. Timmers Paul: Electronic Commerce: Strategies and Models for Business to Business Trading. Chichester: Wiley: 1999.

46. Werbach Kevin: Syndication: The Emerging Model for Business In the Internet Era. Harvard Business Review, Boston, 78 (2000), 5-6: 85-93.

47. Zerdick et al.: E-Conomics: Strategies for the Digital Marketplace. Berlin: Springer, 2000. 